\title{
Scientific winds blowing towards Asia
}

\author{
John Denstedt, MD, FRCSC, FACS
}

Richard Ivey Professor and Chair/Chief, Department of Surgery, Schulich School of Medicine \& Dentistry, Western University, London, ON

Cite as: Can Urol Assoc J 2012;6(2):e108-e109; http://dx.doi.org/10.5489/cuaj.12092

$\mathrm{F}$ or centuries, China was the world's dominant civilization, including being the cradle of scientific, engineering and architectural discovery and innovation. Early discoveries in the field of medicine were often dominated by the Chinese, including sterilization by steaming (AD980), documentation of urinary steroids (AD1025), thyroid treatment $\left(4^{\text {th }}\right.$ century $\left.B C\right)$, the discovery of ephedrine $\left(2^{\text {nd }}\right.$ century $\mathrm{AD}$ ) and the association of sweet and fatty foods with diabetes ( $1^{\text {st }}$ century BC). The last several centuries have seen the preeminence of the Western world in scientific discovery and progress. China has been immersed in a period of political and social disruption distracting from its traditional place in the world of science and innovation - this is beginning to change.

Zhou and colleagues in the April issue of CUAJ highlight trends in scientific publications emanating from mainland China, Taiwan and Hong Kong in urology and nephrology over a recent 10-year period. ${ }^{1}$ The authors surveyed Pub Med and the ISI database and examined the number of articles, impact factors of the journals in which these were published and citations from 2000 to 2009 and extracted data for quantity and quality comparisons. The results are fascinating and highlight the rapid increase in scientific publications coming from these areas most notably, mainland China. The comparison of the total number of articles from each of the three regions may be of less relevance in the long term given the discrepancy in population base and overall size, with mainland China at over 1.3 billion in population versus Taiwan at 23 million and Hong Kong at 7 million. Nonetheless, at the present time, considering numbers of scientific publications alone, almost half come from Taiwan, about a third from mainland China and $17 \%$ from Hong Kong. The more compelling information is the increase in numbers of scientific publications over this 10 -year period. The overall number of publications emanating from mainland China increased 10-fold over this period as compared to a threefold increase from Taiwan and less than a twofold increase from Hong Kong. This trend seems likely to continue given the massive size of mainland China with respect to almost any metric that one might care to measure.

Scientific publications are not just an issue of quantity of course, but quality as well. In this respect, the authors' findings are also interesting. The impact factor of the journals in which articles were published is lowest from mainland China at 2.6 and highest from Hong Kong at 3.5. This is a strong indication that the overall quality of scientific material being published from Hong Kong at the present time remains the highest, but again the mainland Chinese are gaining quickly. The total number of citations for scientific papers over this 10-year period was highest from Taiwan, but over the most recent 5-year period, mainland China assumed the lead position with total number of citations.

The rise of Asia, where half of humanity lives, is transforming the world's economic and geopolitical landscape. Six of the 10 largest cities are there; within 20 years, Asia will be home to three of the four largest economies, including China, India and Japan. This shift in economic clout towards Asia is being paralleled by an increase in focus on scientific research and overall academic productivity. The Chinese, most significantly in mainland China, are shifting from an economy based on low-end manufacturing, such as textiles and children's toys, to one based on innovation and scientific discovery reassuming the role once held by Chinese civilization. The Chinese government is investing heavily in research and development, including in life sciences. Already, as purely measured by the number of published papers, China is the second most productive scientific nation on earth. Chinese universities are creeping up the world's rankings as are their medical schools - many Chinese schools are now listed in the top 100 globally.

Expert scientists among the Chinese diaspora trained in Western laboratories are returning to their homeland in increasing numbers. They bring along their knowledge base and expertise. The substantial investments of The China 
Scholarship Council, affiliated with the Ministry of Education of China, allow mainland Chinese citizens and students to travel abroad and further develop their scientific expertise. This is a highly motivated population whose impact on the field scientific endeavour is just beginning to be felt. An area for improvement is the overall quality of scientific investigation and publications coming from mainland China. ${ }^{2}$

There is an opportunity for Canadian science and urology in all of this. The Canadian government has recently reengaged significantly with China. Education and educational exchanges have been identified as a priority. The CIHR funds joint research programs between Canada and China. The Canada China Scholars Exchange Program, based on reciprocal agreements between the government of Canada and the government of the People's Republic of China, provides the opportunity for faculty members or students at Canadian universities to undertake studies in China. ${ }^{3}$

The Canadian Urological Association has recently developed a nascent relationship with the other CUA, the Chinese Urological Association. This is a cooperation that should be developed further. Universities in Western countries, including those from Canada, are beginning to develop partnerships with Chinese universities and medical schools. ${ }^{4}$

We increasingly live in a global world and as the geopolitical and scientific winds continue to blow towards Asia, there will be both challenges but also opportunities that should be grasped and fostered. In the long run, Chinese contributions to science will only help to improve the overall human condition.

Competing interests: None declared.

This paper has been peer-reviewed.

\section{References}

1. Zhou $X$, Xing C, Xin L, et al. Scientific publications in urology and nephrology journals from China: A 10-year analysis. Can Urol Assoc J 2012;6:102-6. http://dx.doi.org/10.5489/cuaj.11125

2. The Economist. Scientists behaving badly. October 7, 2010. http://www.economist.com/ node/17199386. Accessed April 10, 2012.

3. Government of Canada. Canada-China Scholars' Exchange Program. http://www.scholarships-bourses. gc.ca/scholarships-bourses/can/ccsep-peucc.aspx?lang=eng\&view=d . Accessed April 10, 2012.

4. Dobson W. Canada, China, and Rising Asia: A Strategic Proposal. Rotman School of Management, University of Toronto. http://www.ccbc.com/wp-content/uploads/2011/11/Strategic-proposalENGLISH-25-oct-low-resolution-l.pdf. Accessed April 10, 2012.

Correspondence: Dr. John Denstedt, Schulich School of Medicine \& Dentistry, Western University, 268 Grosvenor St., London, ON N6A 4V2; john.denstedł@sihc.london.on.ca 